\title{
PROROZWOJOWE ODDZIAŁYWANIE FUNDUSZY UNIJNYCH. PERSPEKTYWA POWIATU TORUŃSKIEGO
}

\section{PRO-DEVELOPMENT IMPACT OF EUROPEAN FUNDS FROM THE PERSPECTIVE OF TORUN DISTRICT}

\section{Streszczenie}

Po przystąpieniu Polski do Unii Europejskiej nasz kraj stał się beneficjentem zewnętrznej pomocy finansowej na dotychczas niewystępującą skalę. Powiat Toruński dzięki dużemu zaangażowaniu władz i pracowników pozyskał bardzo wysokie kwoty na projekty, dzięki realizacji których wsparty został rozwój infrastruktury, poprawie uległo bezpieczeństwo oraz opieka medyczna sprawowana nad mieszkańcami. Duże inwestycje objęły też tzw. kapitał ludzki - między innymi w postaci pieniędzy na edukację, aktywizację bezrobotnych i wykluczonych.

Słowa kluczowe: fundusze Unii Europejskiej; samorząd powiatowy; finanse samorządowe.

\section{Summary}

After Polish accession to the EU our country became a beneficiary of external financial help at the scale not witnessed earlier. The Torun District thanks to the involvement of its local government members as well as its employees managed to absorb grant share of available money. It supported the development of infrastructure 
improving level of safety and health care. A lot of money was also invested into the development of so called human capital - among others into fields of education and helping unemployed and socially excluded.

Keywords: EU grants; poviat self-government; self-government finance.

\section{Powiat toruński - skrócona charakterystyka}

Powiat toruński położony jest na terenie województwa kujawsko-pomorskiego i stanowi jeden z 19 powiatów wchodzących w jego skład. To tak zwany ,powiat obwarzankowy” - tworzony przez jedną gminę miejską oraz osiem gmin wiejskich, okalających centralnie położone miasto Toruń. Jedynym miastem powiatu jest 15-tysięczna Chełmża. W powiecie toruńskim jest 131 sołectw oraz 179 miejscowości wiejskich ${ }^{1}$. Pod względem powierzchni $\left(1230 \mathrm{~km}^{2}\right)$ powiat ten zajmuje 4. miejsce w województwie i $77 . \mathrm{w} \mathrm{kraju}^{2}$.

Obszar powiatu toruńskiego należy do trzech regionów Polski: Kujaw, ziemi dobrzyńskiej i ziemi chełmińskiej, co skutkuje jego dużym zróżnicowaniem pod względem historycznym, geograficznym i środowiskowym ${ }^{3}$. Blisko dwie trzecie powierzchni powiatu toruńskiego to bardzo dobre gleby rolnicze - III i IV klasy bonitacyjnej ${ }^{4}$. Zasoby te stwarzają szczególnie dogodne warunki dla rozwoju rolnictwa, osadnictwa oraz rekreacji i turystyki w wymiarze lokalnym i regionalnym.

Oprócz wymienionych czynników endogennych rozwój powiatu silnie determinują czynniki egzogenne. Jako pierwszy z nich i szczególnie istotny należy wymienić bliskość Torunia - miasta, które z liczbą ludności 203158 mieszkańców zajmuje drugie miejsce w województwie kujawsko-pomorskim i szesnaste w kraju ${ }^{5}$. O sile jego oddziaływania decyduje m.in. to, że jest ważnym centrum edukacyjnym, siedzibą kilku uczelni wyższych z Uniwersytetem Mikołaja Kopernika na czele, ośrodkiem kulturalnym i turystycznym o ogólnoświatowej renomie, regionalnie bardzo istotnym centrum

$1 \quad$ Powiaty i gminy w województwie kujawsko-pomorskim w 2014 r., GUS, Bydgoszcz 2016, s. 193.

$2 \quad$ Powierzchnia i ludność w przekroju terytorialnym w 2015 r., GUS, Warszawa 2015.

3 Zob. Miłoszewski H., Powiat toruński-przewodnik, Toruń 2007.

4 J. Małecki, A. Bystrzycki, Środowisko przyrodnicze powiatu toruńskiego, Toruń 2000, s. 81 .

5 Powiaty i gminy..., s. 18. 
gospodarczym ${ }^{6}$, dostarczycielem wielu miejsc pracy oraz ważnym ośrodkiem usług medycznych.

Przy rosnącym zapotrzebowaniu Torunia na tereny inwestycyjne i mieszkaniowe dostępność w powiecie gruntów obu rodzajów przeznaczenia sprzyja dynamicznemu przyrostowi liczby ludności w podtoruńskich gminach. Od momentu utworzenia powiatu liczba jego mieszkańców, przy stałej tendencji wzrostowej wzrosła z poziomu 81554 w 1998 r. ${ }^{7}$ do 102167 w 2014 r. ${ }^{8}$

Drugim czynnikiem zewnętrznym w znaczący sposób determinującym rozwój powiatu toruńskiego jest jego bardzo dogodne, centralne położenie. Województwo kujawsko-pomorskie leży w środkowej części Polski, powiat zaś znajduje się w samym jego centrum. Dzięki temu na jego terenie krzyżują się 4 linie kolejowe, w tym linia Piła-Kutno i Poznań-Olsztyn oraz autostrada A1, drogi krajowe nr 91 (Gdańsk-Katowice), nr 10 (Szczecin-Warszawa), nr 15 (Poznań-Olsztyn) i nr 80 (Bydgoszcz-Lubicz). Ponadto dobrze rozwinięta i utrzymana sieć dróg krajowych, wojewódzkich, powiatowych oraz gminnych zapewnia dogodną komunikację na zewnątrz i wewnątrz powiatu.

Pomimo tego, iż województwo kujawsko-pomorskie należy do najsłabszych gospodarczo regionów kraju', pozycja powiatu toruńskiego na jego tle jest dobra. W roku 2014 dochody własne budżetu powiatu w przeliczeniu na jednego mieszkańca umiejscowiły go na pierwszej lokacie wojewódzkiej ${ }^{10}$, zaś pod względem produkcji sprzedanej przemysłu na 1 mieszkańca powiat zajmuje wysoką, czwartą pozycję ${ }^{11}$. W całym województwie sytuacja na rynku pracy nie jest dobra - w 2015 r. zajmowało ono czternaste miejsce na szesnaście województw. Ze stopą bezrobocia w $2014 \mathrm{r}$. wynoszącą 17,9\% powiat plasuje się powyżej średniej wojewódzkiej (15,5\%), oraz znacząco powyżej

6 W 2015 roku na liście 500 największych polskich przedsiębiorstw publikowanej przez dziennik Rzeczpospolita znalazło się 19 firm z województwa kujawsko-pomorskiego. Najwięcej, bo aż 7 pochodziło z Torunia, http://nowosci.com.pl/333830,500-najwiekszych-firm-Rzeczpospolitej-19-firm-z-regionu-w-tym-az-7-z-Torunia.htm (dostęp: 11.07.2016 r.).

7 Województwo kujawsko-pomorskie w 1998 r. Ważniejsze dane o województwie, powiatach, gminach, WUS, Bydgoszcz 1999.

8 Statystyczne Vademecum Samorzadowca. Powiat toruński, GUS, Bydgoszcz 2015.

9 Zob. Statystyczne Vademecum Samorzadowca. Województwo kujawsko-pomorskie, GUS, Bydgoszcz 2015.

10 Statystyczne Vademecum Samorzadowca. Powiat toruński, GUS, Bydgoszcz 2015.

11 Tamże. 
średniej krajowej $(11,4 \%)^{12}$. Podkreślić jednak należy, że poziom średniej wojewódzkiej stopy bezrobocia jest znacząco zaniżany przez duże miasta, takie jak Bydgoszcz i Torun. Dlatego pośród powiatów województwa kujawsko-pomorskiego powiat toruński zajmuje czwartą pozycję, relatywnie dobrą w porównaniu z powiatami położonymi w południowo-wschodniej części kujawsko-pomorskiego, gdzie bez pracy jest 22,3-25,5\% mieszkańców. Na notowany w ostatnich latach systematyczny spadek wskaźników stopy bezrobocia ${ }^{13}$ wpływ mają ożywienie gospodarcze, wchodzenie na rynek pracy roczników z okresu niżu demograficznego oraz duże saldo zewnętrznych migracji na stałe.

Podsumowując - korzystne, centralne położenie na mapie kraju, dogodne warunki komunikacyjne, bliskość Torunia oraz atrakcyjne tereny pod zabudowę i działalność gospodarczą stanowią istotne atuty powiatu toruńskiego. Dzięki nim obszar ten postrzegany jest jako bardzo dogodne miejsce zamieszkania i prowadzenia aktywności zawodowej, co skutkuje stałym przyrostem liczby jego ludności.

\section{2004 - przystąpienie Polski do UE - obawy i wątpliwości}

Gdy w czerwcu 2003 r. Polacy udzielali odpowiedzi na pytanie „Czy wyraża Pani/Pan zgodę na przystąpienie Rzeczypospolitej Polskiej do Unii Europejskiej?" do urn referendalnych udało się 58,85\% uprawnionych do głosowania. Blisko jedna czwarta z nich (22,55\% głosów ważnych $)^{14}$ takiej zgody nie wyraziła. Niska frekwencja oraz duży odsetek przeciwników integracji - pomimo intensywnej, kilkumiesięcznej kampanii przedreferendalnej - świadczyć mogły o braku przekonania do idei wspólnej Europy oraz uznaniu tej sprawy za nieszczególnie istotną. Tymczasem bilans dwunastoletniej obecności Polski w UE ukazuje doniosłość tego wydarzenia, które wprowadziło zasadnicze zmiany we wszystkich aspektach życia Polaków.

12 Statystyczne Vademecum Samorządowca. Województwo kujawsko-pomorskie, GUS, Bydgoszcz 2015.

13 Por. Statystyczne Vademecum Samorządowca. Województwo kujawsko-pomorskie z ubiegłych lat.

14 Obwieszczenie Państwowej Komisji Wyborczej z dnia 21 lipca 2003 r. o skorygowanym wyniku ogólnokrajowego referendum w sprawie wyrażenia zgody na ratyfikację Traktatu dotyczącego przystąpienia Rzeczypospolitej Polskiej do Unii Europejskiej (Dz.U. z 2003 r. Nr 132, poz. 1223). 
Pomimo wcześniej sygnalizowanych obaw ${ }^{15}$ dzięki podjęciu licznych reform i działań o charakterze prawnym, gospodarczym czy infrastrukturalnym, które systematycznie zbliżają nasz kraj do unijnego poziomu, niedawny bilans dziesięciolecia funkcjonowania Polski w strukturach Unii Europejskiej wskazał na weryfikację wcześniej wyrażanych obaw ${ }^{16}$ i znaczącą poprawę nastrojów. Mimo poniesionych kosztów społecznych i gospodarczych, akceptacja członkostwa w UE jest obecnie powszechna - w marcu 2014 r. 89\% ankietowanych przez CBOS zadeklarowało się jako zwolennicy obecności Polski w UE, przy zaledwie $7 \%$ przeciwników i $4 \%$ niezdecydowanych ${ }^{17}$. Przekonanie o tym, że dzięki integracji Polska odniosła więcej korzyści niż strat jest dość powszechne - bilans integracji pozytywnie postrzega $62 \%$ badanych przez CBOS, in minus oceniło go $13 \%$ ankietowanych, zaś $20 \%$ respondentów uważało, że korzyści i straty związane z członkostwem Polski w Unii równoważą się ${ }^{18}$.

Niewątpliwie bardzo duże znaczenie dla tej zmiany poglądów i przekonań Polaków ma szeroki strumień funduszy europejskich, skierowanych do naszego kraju głównie w celu realizacji polityki spójności i wspólnej polityki rolnej. Dzięki niemu nastąpiło bowiem bezprecedensowe przyspieszenie rozwoju i miało miejsce wiele pozytywnych zmian, takich jak poprawa stanu infrastruktury, wzrost bezpieczeństwa na drogach, dofinansowanie ochrony zdrowia, rozwój przedsiębiorstw i duże inwestycje w kapitał ludzki.

\section{Samorząd - reprezentant społeczeństwa}

Piętnaście lat przed przystąpieniem naszego kraju do Unii Europejskiej Polska doświadczyła procesu głębokiej transformacji ustrojowej. Szereg doniosłych przeobrażeń politycznych, gospodarczych, społecznych i kulturowych

15 Zob. m.in.: J. Szymańczak, Konferencja Od przeszłości do przyszłości samorzadu powiatowego, Warszawa, 18 lutego 2013 r., Kancelaria Sejmu, Warszawa 2013; J. Osiecka, Opinia publiczna o integracji europejskiej-wyzwania dla polityki informacyjnej państwa. Raport nr 156, Biuro Studiów i Ekspertyz, Warszawa 1999, http://biurose.sejm.gov.pl/ teksty/r-156.htm (dostęp: 07.07.2014 r.), http://ec.europa.eu/polska/news/opinie/090824_j. kucharczyk_polacy_5_lat_po_wejsciu_do_ue_pl.htm,(dostęp 07.07.2014).

16 Zob. rozdział Weryfikacja obaw Polaków zgłaszanych przed wejściem Polski do UE, [w:] 10 PL-UE. Polskie 10 lat w Unii. Raport, praca zbiorowa, Ministerstwo Spraw Zagranicznych, Warszawa 2014, s. 223-233.

17 Komunikat z badań CBOS nr 52/2014 - 10 lat członkostwa Polski w Unii Europejskiej, Fundacja Centrum Badania Opinii Społecznej, Warszawa, kwiecień 2014.

18 Tamże. 
nadał krajowi nowy - organizacyjny i instytucjonalny - wymiar. Jednym z istotnych rozwiązań było przywrócenie samorządności terytorialnej, która poprzez budowanie postaw zaangażowania i samoorganizacji, służyć miała utworzeniu państwa obywatelskiego. Wprowadzony w dwóch etapach trójstopniowy podział terytorialny Polski (1990 - gminy, 1999 - samorządowe powiaty i województwa) zapoczątkował funkcjonowanie instytucji samorządowych. Miały one dzięki zaangażowaniu społeczności lokalnych i ich poczuciu odpowiedzialności za własny los umożliwiać jak najsprawniejsze diagnozowanie i zaspokajanie ich własnych potrzeb. Wydaje się, iż założenie to udało się zrealizować w należytym stopniu, gdyż poczucie indywidualnego wpływu na lokalną sytuację systematycznie wzrasta - od niskiego poziomu 16\% w 1992 roku aż po $52 \% \mathrm{w}$ roku $2010^{19}$. Stąd uprawnione jest stwierdzenie, że ,samorząd terytorialny na trwałe wpisał się w administracyjny i obywatelski pejzaż kraju" ${ }^{20}$, a samorządowe gminy, powiaty i województwa „stały się częścią demokratycznego państwa prawnego, pobudziły społeczny i gospodarczy rozwój Polski [oraz] przyczyniły się do upodmiotowienia wspólnot lokalnych."21 Ugruntowaną pozycję polskiego samorządu potwierdza również niezmiennie od lat pozytywna opinia przeważającej większości Polaków - aż 62\% dobrze ocenia działalność władz lokalnych w swojej miejscowości, przeciwnego zdania jest natomiast 29\%. Zaznaczyć należy, że pozytywne wypowiedzi częściej pochodzą od mieszkańców wsi, zaś negatywne - od osób zamieszkujących największe aglomeracje ${ }^{22}$. To pozwala postawić tezę, iż działalność samorządowa w mniejszych miejscowościach jest dla lokalnej społeczności bardziej „widoczna”, gdyż związana z konkretnymi osobami i odpowiadająca na bardziej osobiste potrzeby mieszkańców. Może być dzięki temu oceniana lepiej, niż łatwiej rozmywająca się w mnogości załatwianych spraw i miejskiej przestrzeni aktywność władz w większych aglomeracjach. Potwierdzenie tej tezy stanowić może również schemat postrzegania wpływu jednostek samorządu terytorialnego na życie lokalnych społeczności - im niższy szczebel

19 Komunikat z badań CBOS nr 69/2015 - 25 lat państwa obywatelskiego. Spoleczne oceny samorzadności terytorialnej, Fundacja Centrum Badania Opinii Społecznej, Warszawa, maj 2015.

20 Narastajace dysfunkcje, zasadnicze dylematy, konieczne działania. Raport o stanie samorzadności terytorialnej w Polsce, praca zbiorowa, Małopolska Szkoła Administracji Publicznej, Kraków 2013, s. 9.

21 Tamże.

22 Komunikat z badań CBOS nr 36/2014 - Oceny instytucji publicznych, Fundacja Centrum Badania Opinii Społecznej, Warszawa, marzec 2014. 
administracji samorządowej, czyli zarówno fizycznie, jak i mentalnie bliższy mieszkańcom danego terenu, tym rola przez niego pełniona uważana jest za istotniejszą. O tym, że rozwój miejscowości w której żyją, w znacznym stopniu zależy od samorządu gminnego przekonane jest trzy piąte badanych (58\%), podczas gdy mniej niż połowa dostrzega dużą rolę samorządu szczebla powiatowego (45\%), a już tylko ponad jedna trzecia - samorządu wojewódzkiego $(37 \%)^{23}$.

\section{Samorząd terytorialny - ważnym gestorem i beneficjentem środków z UE}

Należyte sprawowanie władzy przez przedstawicieli samorządu terytorialnego, zyskujące społeczną akceptację i poparcie jawi się w świetle akcesji Polski do UE jako kluczowe. To bowiem polskim samorządom powierzono bardzo ważną i odpowiedzialną rolę - gestorów i beneficjentów bezprecedensowej w swej wielkości i zakresie zewnętrznej pomocy finansowej. „Z badań [Instytutu Spraw Publicznych] wyraźnie wynika [bowiem], że to właśnie fundusze unijne kojarzą się najbardziej z całym procesem integracji i członkostwa w Unii Europejskiej. Odpowiadając na pytania dotyczące korzyści i strat z akcesji, przedstawiciele samorządu terytorialnego często podkreślają kluczową rolę funduszy i często to właśnie przez pryzmat efektywności ich pozyskiwania i wykorzystania oceniają Polskę (...)"24.

Dane prezentowane na oficjalnej stronie www.funduszeeuropejskie.gov.pl wskazują, iż to właśnie samorządy są największym beneficjentem europejskich pieniędzy. Zrealizowały one w latach 2007-2013 przedsięwzięcia o największej łącznej wartości unijnego dofinansowania - 73,6 mld złotych, co stanowi $31 \%$ wszystkich funduszy i daje samorządom prymat przed takimi grupami jak przedsiębiorstwa (30\%), a nawet organy władzy i administracji rządowej $(24 \%)^{25}$. Dane te dobitnie świadczą o tym, jak wielka odpowiedzialność za prawidłowe wykorzystanie przyznanego wsparcia spoczywa na polskim samorządzie terytorialnym.

23 Komunikat z badań CBOS nr 69/2015 - 25 lat państwa obywatelskiego...

24 Ł. Wenerski, Unia daje czy zabiera? Dekada czlonkostwa polski w UE $w$ oczach przedstawicieli polskich samorzadów, Instytut Spraw Publicznych, Warszawa 2013, s. 28.

25 http://www.funduszeeuropejskie.gov.pl/2014_2020/Strony/Doskonala_decyzja_dla_inwestycji_samorzadowych_29082013.aspx (dostęp: 09.07.2014 r.). 
To ważne ogniwo w absorpcji środków unijnych stanowiły i wciąż stanowią samorządy wszystkich trzech szczebli. Samorządowe województwa występują w wielorakiej roli - jako instytucje zarządzające, instytucje pośredniczące czy beneficjenci lub liderzy i partnerzy w projektach, natomiast powiaty i gminy jako beneficjenci, liderzy lub partnerzy tych projektów. Samorządy odgrywają zatem bardzo odpowiedzialną rolę, ponieważ swymi działaniami i aktywnością wpływają bezpośrednio na sposób i poziom wykorzystania unijnych pieniędzy, m.in. poprzez decyzje na co środki z UE będą wydawane. Samorządy, działając w swoich lokalnych i regionalnych wspólnotach, dysponują wiedzą dotyczącą potrzeb oraz możliwości wykorzystania unijnych pieniędzy zaczerpniętą bezpośrednio od mieszkańców. Oparta jest ona o obserwację zachodzących na swoim terenie zmian społecznych, infrastrukturalnych oraz gospodarczych, dzięki czemu stanowi bardziej bezpośrednie i dokładne rozpoznanie, niż to, jakim dysponuje władza centralna z poziomu administracji państwowej w Warszawie.

Środki unijne pozwalają na realizację dwóch zasadniczych typów projektów. Pierwszą stanowią tzw. działania „miękkie” - tzn. szkolenia, warsztaty, imprezy, drugą projekty „twarde”, czyli inwestycyjne, takie jak budowa i modernizacja infrastruktury drogowej, wodno-kanalizacyjnej, mieszkaniowej itp. Powstałe przez lata zaniedbań duże zapóźnienia cywilizacyjno-rozwojowe spowodowały, że polskie samorządy jako najważniejsze postrzegały projekty infrastrukturalne - 98\% polskich samorządów ankietowanych przez Instytut Spraw Publicznych wskazało ten rodzaj działań jako priorytet w kwestii poszukiwania unijnych środków, a $96 \%$ przeprowadziło w tym obszarze realne inwestycje. Pomimo tak dużego zastrzyku gotówki, braki w infrastrukturze nadrabiane będą jeszcze przez lata. Kolejne trzy obszary wskazywane przez samorządy jako najistotniejsze i zarazem takie, na które przeznaczone zostało najwięcej unijnego wsparcia, to inwestycje z zakresu ochrony środowiska (odpowiednio 59\% i 50\%) inwestycje kulturalne (37\% / 36\%) oraz wspieranie zatrudnienia $(34 \% / 25 \%)^{26}$. Warto zwrócić uwagę na to, że deklarowane w badaniu priorytety i kierunki realnych działań są z sobą w dużym stopniu zbieżne - co oznacza, że samorządy co do zasady angażują siły i środki zgodnie ze zdiagnozowanymi potrzebami i w sposób racjonalny oraz efektywny. Sami samorządowcy zadowoleni są z podejmowanych w tym zakresie własnych działań i decyzji - uważając w większości, że fundusze europejskie

$26 \quad$ Ł. Wenerski, Unia daje czy zabiera?..., s. 30. 
wykorzystywane są w ich regionie zdecydowanie (59\%) lub raczej dobrze (39\%). Przeciwnego zdania jest zaledwie 3\% respondentów ${ }^{27}$.

Pomimo tak dużego napływu środków finansowych i przeważnie starannego i właściwego nimi dysponowania, ponad połowa ankietowanych samorządowców (52\%) zauważyła, że na potrzeby ich jednostki samorządu terytorialnego ilość unijnych pieniędzy jest zbyt mała ${ }^{28}$. Zaznaczyć należy jednak, że często niedofinansowane polskie samorządy zapominają o jednej z podstawowych zasad polityki regionalnej UE, a mianowicie zasadzie dodatkowości, zwanej również zasadą współfinansowania lub uzupełnienia. Mówi ona o tym, że fundusze unijne powinny stanowić jedynie uzupełnienie środków finansowych państw członkowskich, a nie je całkowicie zastępować, a działania Unii nie mają za zadanie wypierać ani zastępować działań na szczeblu krajowym i regionalnym, lecz je wzbogacać i wzmacniać29. Jednak polskie samorządy, znajdujące się w przeważającej części w bardzo złej kondycji finansowej ${ }^{30}$, postrzegają fundusze unijne jako często jedyne źródło dodatkowych pieniędzy, z których mogą sfinansować najpilniejsze potrzeby inwestycyjne. Nic zatem dziwnego, że niezależnie od ilości dostępnych środków, samorządy stale odczuwają ich niedosyt. Ponadto należy zaznaczyć, ze specyfika programowania powoduje, że nie zawsze środki są dostępne na taki rodzaj działań, które z punktu widzenia lokalnych społeczności są najbardziej potrzebne i pożądane.

Pozyskując i wdrażając projekty współfinansowane $z$ funduszy europejskich, samorządy konfrontują się z licznymi barierami i problemami, gdyż aplikowanie o środki unijne, prowadzenie projektów, rozliczanie ich, a następnie poddawanie się kontroli nie jest zadaniem prostym, a ewentualne przeszkody i końcowe efekty bywają nie zawsze przewidywalne. Pośród najczęstszych niedogodności samorządowcy wskazują na nadmierną komplikację procedur (78\%), barierę finansową, zbyt duży wkład własny (68\%), brak czasu/zbytnie przeciążenie pracowników innymi obowiązkami (47\%) czy trudności z prawidłowym przygotowaniem wniosków $(51 \%)^{31}$.

\footnotetext{
27 Tamże, s. 31.

28 Tamże, s. 30.

29 http://www.funduszeeuropejskie.gov.pl/organizacjafunduszyeuropejskich/Strony/czymsafundusze.aspx (dostęp:10.07.2014 r.).

30 Zob. Ocena sytuacji samorządów lokalnych, Ministerstwo Administracji i Cyfryzacji, https://mac.gov.pl/files/ocena-sytuacji-samorzadow-lokalnych.pdf (dostęp:10.07.2014 r.).

31 Ł. Wenerski, Unia daje czy zabiera?..., s. 31.
} 
Niewątpliwie percepcja funduszy europejskich oraz ocena ich dostępności i łatwości wykorzystania może być różna dla różnych perspektyw finansowych. Możliwości aplikacji o fundusze europejskie ulegały bowiem różnego rodzaju zmianom w ramach wszystkich trzech kolejnych okresów programowania.

Pierwszy z nich, najkrótszy, który obejmował lata 2004-2006 umożliwiał absorpcję unijnego wsparcia poprzez następujące programy:

1. Zintegrowany Program Operacyjny Rozwoju Regionalnego,

2. Sektorowy Program Operacyjny Rozwój Zasobów Ludzkich,

3. Inicjatywa Wspólnotowa EQUAL,

4. Sektorowy Program Operacyjny Wzrost Konkurencyjności Przedsiębiorstw,

5. Sektorowy Program Operacyjny Transport,

6. Sektorowy Program Operacyjny Pomoc Techniczna,

7. Inicjatywa Wspólnotowa INTERREG,

8. Sektorowy Program Operacyjny Restrukturyzacja i Modernizacja Sektora Żywnościowego oraz Rozwój Obszarów Wiejskich,

9. Sektorowy Program Operacyjny Rybołówstwo i Przetwórstwo Ryb.

Pierwszą pełną siedmioletnią perspektywą była ta realizowana w latach 2007-2013. Unijne fundusze dostępne były poprzez 5 krajowych programów operacyjnych zarządzanych przez Ministerstwo Infrastruktury i Rozwoju, 16 programów regionalnych, realizowanych w poszczególnych województwach i zarządzanych przez Urzędy Marszałkowskie oraz poprzez programy Europejskiej Współpracy Terytorialnej. Były to następujące programy operacyjne:

1. Program Infrastruktura i Środowisko,

2. Program Innowacyjna Gospodarka,

3. Program Kapitał Ludzki,

4. Program Rozwój Polski Wschodniej,

5. Program Pomoc Techniczna,

6. Programy Europejskiej Współpracy Terytorialnej,

7. Regionalne Programy Operacyjne (po 1 dla każdego z województw).

Obecna perspektywa 2014-2020 oferuje beneficjentom 6 krajowych programów operacyjnych zarządzanych przez Ministerstwo Infrastruktury i Rozwoju, 16 wojewódzkich programów regionalnych zarządzanych przez odpowiednie Urzędy Marszałkowskie oraz programy Europejskiej Współpracy Terytorialnej. Te programy to:

1. Program Infrastruktura i Środowisko,

2. Program Inteligentny Rozwój, 
3. Program Wiedza Edukacja Rozwój,

4. Program Polska Cyfrowa,

5. Program Polska Wschodnia,

6. Program Pomoc Techniczna,

7. Programy Europejskiej Współpracy Terytorialnej,

8. Regionalne Programy Operacyjne (1 dla każdego z województw).

Tematyka niniejszego opracowania nie obejmuje analizy różnic pomiędzy poszczególnymi programami, tym niemniej zauważyć należy, że z perspektywy samorządowej zasadnicze obszary wsparcia (szczególnie w przypadku pierwszych dwóch okresów programowania) były zbliżone, natomiast dużemu zróżnicowaniu ulegała forma ich dostępności. Formalne wymagania stawiane beneficjentom zarówno na etapie pisania projektu, jak i na etapie jego realizacji oraz późniejszej kontroli ulegały coraz większej formalizacji i zaostrzeniu. O ile pierwszą perspektywę porównać można w pewnym stopniu do zasad rządzących wydatkowaniem i rozliczaniem środków przedakcesyjnych, to już trzecia perspektywa jest znacząco bardziej zbiurokratyzowana - przy niedużych nawet projektach wnioski liczyć potrafią kilkadziesiąt stron. Podobnie jest z ilością wymaganych załączników, zaś objętość wytycznych również wzrosła kilkunastokrotnie. Rosnące sformalizowanie idzie w parze z ograniczeniami dotyczącymi swobody wyboru form realizacji wsparcia, co w znaczącym stopniu obniża poziom dopasowania projektów do lokalnych potrzeb i pogarsza wskaźnik optymalizacji wykorzystania środków. Kolejnym problemem są narastające $\mathrm{z}$ każdą kolejną perspektywą finansową opóźnienia w opracowywaniu, a tym samym udostępnianiu beneficjentom dokumentacji umożliwiających start w konkursach. W efekcie w połowie roku 2016 ruszają pierwsze konkursy w ramach perspektywy, która rozpoczęła się w roku 2014.

Obecny okres programowania 2014-2020 oparty jest o tzw. Strategię Europa 2020 i określone przez nią priorytety. Obowiązujące obszary pomocowe to trzy rodzaje rozwoju: inteligentny (czyli oparty na wiedzy i innowacjach), zrównoważony (czyli transformacja w kierunku gospodarki niskoemisyjnej, konkurencyjnej i efektywnie korzystającej z zasobów) oraz rozwój sprzyjający włączeniu społecznemu (czyli tworzenie gospodarki charakteryzującej się wysokim poziomem zatrudnienia i zapewniającej spójność gospodarczą, społeczną i terytorialną). Wzrasta zatem istotnie znaczenie działań o charakterze „miękkim”, stawiających w ostatecznym rozliczeniu na człowieka oraz 
projektów opartych o innowacyjność i rozwijające się technologie, co powoduje, że duża część unijnych pieniędzy, choć kwotowo dużych, jest niedostępna dla mniejszych samorządów.

Obchodzone w ubiegłym roku dwudziestopięciolecie restytucji samorządu wyzwoliło ogólnopolską debatę oceniającą kondycję polskiej samorządności ${ }^{32}$. Dyskusja ta miała charakter wielowątkowy, ukazując obszary siły i słabości funkcjonującego systemu ${ }^{33}$. W świetle tematyki niniejszego artykułu, z punktu widzenia powiatu toruńskiego jednym ze szczególnie dotkliwie odczuwanych problemów jest kryzys zaufania władzy centralnej do instytucji samorządowych, objawiający się poprzez systematyczne zawężanie obszaru samorządowej samodzielności. Za przykład może posłużyć tu obszar związanej z unijnymi funduszami polityki rozwoju. Samorządy, pomimo tego, że dobrze przygotowane i dysponujące coraz bardziej kompetentną i fachową kadrą są znacząco ograniczane w sprawowaniu swojej funkcji prorozwojowej, a ograniczenia mają charakter tak instytucjonalny, jak i finansowy. Dobrze sytuację tę ilustruje poniższa opinia: „Faktycznie j.s.t. w niewielkim stopniu wypełniają funkcję rozwojową. Województwa, powiaty i gminy są silnie uzależnione od transferów, dotacji i innych rodzajów wsparcia ze strony centrum. Centralizacja polityki rozwoju regionalnego została umocniona przez wprowadzone mechanizmy rozdzielania środków europejskich. Decentralizacja objęła przede wszystkim funkcje usługodawcze administracji publicznej, a nie rozwojowe. Te ze względu na brak zasobów kapitałowych, brak samodzielności finansowej oraz uzależnienie od subwencji i dotacji nie mogą być realizowane w sposób kompleksowy ${ }^{34}$ ".

Szansa pozyskiwania funduszy unijnych stanowiła dla samorządów tak bardzo oczekiwaną możliwość realizowania własnej polityki, będącej odpowiedzią na potrzeby wyrażane przez lokalne społeczności. Wyraźnie widać jednak tendencję do „usztywniania” zasad rządzących wydatkowaniem europejskich pieniędzy i coraz silniejsze uzależnienie sposobu ich pożytkowania od centralnie narzuconych reguł dotyczących, nie tylko już głównie kwestii formalnych, a szeroko rozumianej merytoryki realizowanych projektów.

32 Zob. A. Lutrzykowski (red.), Polski samorzqd terytorialny. Europejskie standardy i krajowa specyfika, Toruń 2014.

33 Zob. m. in.: A. Dąmbska, S. Trzyna (red.), Samorzad 3.0 Raport Forum Od-nowa, Forum Od-nowa, Warszawa, listopad 2013; Narastajace dysfunkcje, zasadnicze dylematy, konieczne działania. Raport o stanie samorząności...

34 Tamże, s. 74. 


\section{Powiat toruński - beneficjent europejskiej integracji}

Trójstopniowy podział administracji samorządowej oraz samodzielność gmin powodują, że choć powiat i wchodzące w jego skład gminy obejmują ten sam obszar, badając zmiany zachodzące na nim z perspektywy powiatu nie można zaliczyć w ich poczet wyników działań gmin wchodzących w jego skład. Dlatego też należy wyraźnie zaznaczyć, iż na potrzeby niniejszego opracowania przeanalizowane zostały jedynie działania powiatu toruńskiego, jego zarządu, rady oraz Starostwa Powiatowego w Toruniu. Działania gmin i pozostałych podmiotów są przedstawione jedynie w przypadku, gdy współdziałały one z powiatem $\mathrm{w}$ ramach partnerstwa, bądź też gdy obejmują je cytowane zagregowane dane. W związku z opóźnieniami we wdrażaniu perspektywy 2014-2020 przedstawione dane prezentują głównie działania przeprowadzone w latach 2004-2013, podczas obowiązywania dwóch pierwszych okresów programowania.

Od początku, kiedy tylko członkostwo Polski w Unii Europejskiej zaczęło stawać się realne, powiat toruński mocno angażował się w proeuropejskie działania. Od 2003 r. w Starostwie Powiatowym w Toruniu utworzone zostało stanowisko Pełnomocnika Starosty ds. integracji z UE, przekształcone w roku 2007 w Wydział Rozwoju i Projektów Europejskich, funkcjonujący od roku 2014 jako Wydział Promocji i Rozwoju.

Aktywność powiatu toruńskiego w działaniach promujących europejską integrację była dostrzegana i nagradzana na forum ogólnopolskim. Pierwszy raz udziałem uczniów, nauczycieli i władz w debacie parlamentarnej poświęconej integracji Polski z UE po podpisaniu przez Polskę Traktatu Akcesyjnego oraz w spotkaniu z Premierem, Marszałkiem Sejmu i ministrami. Drugim razem, jako wyraz uznania za zaangażowanie na rzecz akcesyjnego referendum powiat odwiedził Prezydent RP Aleksander Kwaśniewski.

Już w czasie poprzedzającym przystąpienie Polski do UE powiat intensywnie korzystał ze środków przedakcesyjnych (np. SAPARD). Tym niemniej rok 2004 stanowił czas przełomu w dostępie do zewnętrznych źródeł finansowania. Od tej daty powiat toruński oraz jego jednostki organizacyjne przeprowadziły obsługę 60 projektów o łącznej wartości $148 \mathrm{mln}$ zł, z czego $80 \%$ dofinansowane zostało przez $\mathrm{UE}^{35}$. Dzięki unijnym funduszom powiat realizuje z sukcesem projekty służące społecznościom lokalnym na całym

35 Te i kolejne dane za: M. Rouba (opr.), 15 lat powiatu toruńskiego..., s. 66. 
jego terytorium, a głównymi obszarami działania i zaangażowania środków stały się edukacja, rynek pracy i poprawa infrastruktury. Działania te służą systematycznemu podnoszeniu komfortu mieszkańców we wszystkich dziedzinach życia.

Dofinansowanie i poprawa jakości edukacji objęły szeroką grupę odbiorców - od najmłodszych, poprzez młodzież i dorosłych chcących uzupełnić wykształcenie po nauczycieli podnoszących zawodowe kwalifikacje. W latach 2004-2013, dzięki realizacji partnerskich projektów z gminami, w 41366 godzinach zajęć dodatkowych wzięło udział 9165 uczniów, a 194 nauczycieli odbyło szkolenia, za łączną kwotę 4,5 mln zł.

Powiat realizuje również projekty dla prowadzonych przez siebie zespołów szkół ze szczególnym uwzględnieniem realizowanego w nich kształcenia zawodowego. Dzięki działalności powiatu oraz projektom własnym szkół, wiedzę i umiejętności rozwijało 2033 uczniów powiatowych techników i zawodówek oraz 833 nauczycieli, a ZS CKU w Gronowie otworzył 35 oddziałów szkół dla dorosłych.

Drugim w kolejności obszarem, na który powiat toruński pozyskał najwięcej środków z Unii Europejskiej, jest rynek pracy. Dzięki aktywności Powiatowego Urząd Pracy dla Powiatu Toruńskiego 43,84 mln zł trafiło do bezrobotnych w postaci staży i szkoleń, pośrednictwa i poradnictwa zawodowego, a także pomocy na założenie własnej firmy. Ze wsparcia skorzystał też sam PUP, zdobywając fundusze na zatrudnienie pośredników pracy i doradców zawodowych, a także szkolenia i upowszechnianie monitoringu zawodów.

Infrastruktura i drogi, to trzeci istotny obszar powiatowej aktywności. Do roku 2016 oprócz środków pozyskiwanych na przebudowę i modernizację dróg z rezerwy subwencji ogólnej Ministerstwa Transportu, Budownictwa i Gospodarki Morskiej (4,1 mln) oraz Narodowego Programu Przebudowy Dróg Lokalnych (14,2 mln), powiat pozyskał 3,3 mln złotych z Regionalnego Programu Operacyjnego oraz 1,6 mln ze Zintegrowanego Programu Operacyjnego Rozwoju Regionalnego ${ }^{36}$. Odrębną inwestycją był realizowany w latach 2008-2015 projekt kluczowy - poprawa bezpieczeństwa na drogach publicznych poprzez budowę dróg rowerowych, o wartości blisko $30 \mathrm{mln}$ złotych. Trzy nowo wybudowane drogi rowerowe umożliwiają wygodne przemieszczanie się po terenie powiatu do zakładów pracy, szkół, urzędów, sklepów, obiektów kulturalnych

36 M. Rouba (opr.), 15 lat powiatu toruńskiego..., s. 55. 
czy kościołów oraz bezpieczny dojazd do głównych atrakcji turystycznych, w tym trzech najpopularniejszych wśród mieszkańców i turystów jezior.

Domy pomocy społecznej i Powiatowe Centrum Pomocy Rodzinie pozyskały w dwóch pierwszych okresach programowania ponad 1,93 $\mathrm{mln}$ zł na aktywizację i integrację społeczną dla swoich podopiecznych. Fundusze unijne pomogły także dostosować obiekty do wymaganych standardów i sfinansować inwestycje w nowoczesne rozwiązania techniczne, takie jak np. instalacja pomp ciepła.

Rys. 1. Powiat toruński - zestawienie obszarów i wartości projektów unijnych w latach 2004-2013.
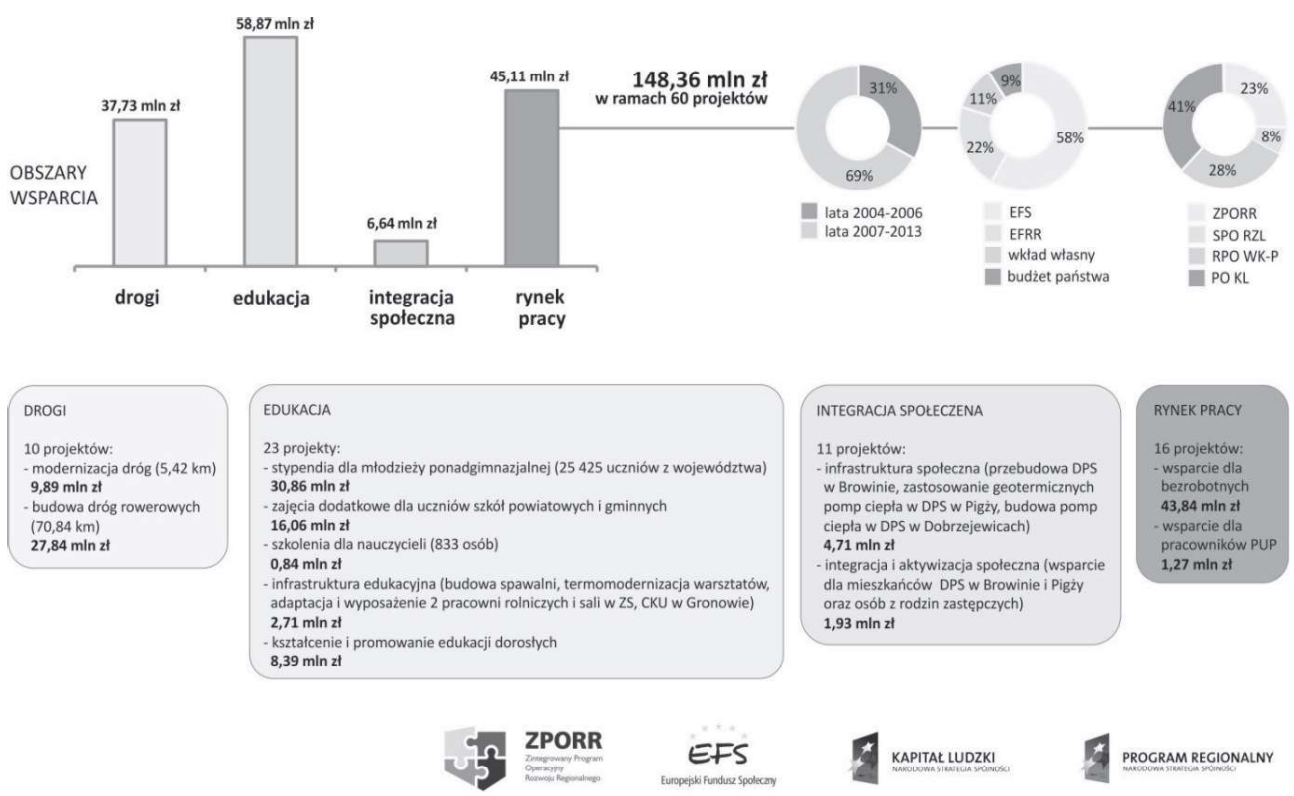

Źródło: M. Rouba (opr.), 15 lat powiatu toruńskiego, Starostwo Powiatowe w Toruniu, Toruń 2014.

Większość zadań powiatu związanych z ochroną zdrowia na terenie powiatu realizuje Szpital Powiatowy sp. z o.o. w Chełmży. Nie jest on jednostką organizacyjną powiatu, ale powiat jest jego głównym udziałowcem (86\%). Jest to efekt pionierskiej na skalę kraju prywatyzacji, gdy w 2001 roku władze powiatu podjęły decyzję o przekształceniu podupadającego i zadłużonego szpitala w spółkę prawa handlowego. Wpłynęło to na znaczącą poprawę finansowej kondycji placówki i zagwarantowało prawidłowe wykonywanie świadczeń medycznych. Inwestując w szpital, powiat sięgnął nie tylko po fundusze 
regionalne (RPO), ale także krajowe (PO Infrastruktura i Środowisko). Całkowity koszt zrealizowanych od 2002 r. inwestycji wyniósł ok. $26 \mathrm{mln}$ zł. Pierwszy etap, w latach 2002-2005, to rozbudowa i doposażenie szpitala z dofinansowaniem UE za kwotę $6 \mathrm{mln}$ zł. Kolejne dwa lata trwał wart $3 \mathrm{mln}$ zł drugi etap inwestycji (PFRON, RPO). Ostatni etap, trzeci, zrealizowany w latach 2009-2011 to koszt $17 \mathrm{mln}$ zł, z czego ponad 5,5 mln pochodziło z budżetu UE. W wyniku reorganizacji i rozbudowy powierzchnia szpitala wzrosła o blisko 50\%, znacząco poprawiło się jego wyposażenie, zakupiono również dwie karetki, w istotnym stopniu skracając dojazd do chorego dla mieszkańców całej północnej części powiatu.

Jednym z największych sukcesów powiatu toruńskiego, stanowiącym pochodną realizacji projektów unijnych, jest wypracowana i udoskonalana przez lata umiejętność tworzenia i prowadzenia projektów partnerskich z przedstawicielami samorządów wszystkich szczebli oraz innymi podmiotami i organizacjami ${ }^{37}$.

Pierwszym tego rodzaju działaniem była realizacja na terenie województwa kujawsko-pomorskiego w ciągu kolejnych lat szkolnych: 2004/5, 2005/6, 2006/7, trzech edycji projektu „Pomoc stypendialna dla uczniów szkół ponadgimnazjalnych województwa kujawsko-pomorskiego" 38 . Powiat toruński był liderem projektu dla trzydziestu jednostek samorządu terytorialnego, czyli wszystkich j.s.t. będących organami prowadzącymi dla szkół ponadgimnazjalnych w województwie kujawsko-pomorskim. O skali projektu świadczyć może liczba beneficjentów kolejnych edycji programu stypendialnego: 9868 , 10406 i 5181 oraz rozdysponowane kwoty: 8756 897,91 PLN, 12498604 PLN i 9608 431,68 PLN ${ }^{39}$. Natomiast o jego szczególnym znaczeniu to, że województwo kujawsko-pomorskie było jednym z dwóch regionów w Pol$\mathrm{sce}^{40}$, w których udało się utworzyć partnerstwo samorządów w celu realizacji

37 Zob. tamże, s. 70.

38 Projekty realizowane w ramach Zintegrowanego Programu Operacyjnego Rozwoju Regionalnego, Działanie 2.2 Wyrównywanie szans edukacyjnych poprzez programy stypendialne, finansowane ze środków Europejskiego Funduszu Społecznego oraz budżetu państwa.

39 Spadek liczby uczniów w III edycji wynikał ze zmian w sposobie przyznawania stypendium, jak również ze znacznego podniesieniu jego wysokości. W okresie trzech lat maksymalna wypłata wzrosła bowiem z 1000, do 1500 i ostatecznie do 2500 zł w skali roku szkolnego.

40 Drugim było województwo świętokrzyskie, w którym rolę koordynatora dla 24 j.s.t. pełnił powiat kielecki, zob. Dz.Urz. Województwa Świętokrzyskiego z 2005 r. Nr 183. 
projektów stypendialnych. Dzięki takiemu rozwiązaniu wykorzystanie środków osiągnęło bezprecedensowy w kraju, blisko stuprocentowy poziom. $\mathrm{Na}$ podkreślenie zasługuje również to, że część jednostek samorządu terytorialnego, z różnych względów, nie była w stanie w pierwszych latach po akcesji poradzić sobie z zadaniem aplikowania o unijne fundusze. Dla nich, znacznie ułatwiony dzięki obsłudze przez powiat toruński dostęp do dofinansowania, stanowił jedyną szansę na skorzystanie z unijnych pieniędzy ${ }^{41}$.

Powiat toruński był również liderem pierwszego innowacyjnego projektu edukacyjnego w województwie kujawsko-pomorskim ${ }^{42}$, realizowanego w latach 2010-2013, prowadzonego w partnerstwie z gminą miasta Włocławek oraz fińskim konsorcjum Keuda. Ideą projektów innowacyjnych było wypracowanie rozwiązań, które mogłyby być stosowane w wymiarze ogólnopolskim. Głównym celem ,Szkoły innowacyjnej i konkurencyjnej - dostosowanie oferty szkolnictwa zawodowego do wymagań lokalnego rynku pracy" było zmniejszenie ryzyka bezrobocia wśród młodzieży poprzez dostosowanie oferty edukacyjnej szkół zawodowych do potrzeb lokalnego rynku pracy i wdrożenie innowacyjnej formy współpracy na linii szkoła-przedsiębiorca-uczeń. Projekt pozwolił na przetestowanie narzędzi pomagających skuteczniej powiązać szkolnictwo zawodowe z pracodawcami ${ }^{43}$, a efekty które przyniósł, prezentowane były na licznych konferencjach branżowych.

Projekty w których powiat toruński brał udział w roli lidera lub partnera w syntetyczny sposób przedstawia poniższa infografika:

41 Zob. przykład powiatu rypińskiego [w:] J. Zając, A. Wojewódzka, M. Stawicki, Uwarunkowania absorpcji funduszy strukturalnych UE na poziomie powiatów. Analiza i rekomendacje, Warszawa 2009, s. 56.

42 Projekt realizowany był w ramach Działania: 9.6 Projekty innowacyjne Programu Operacyjnego Kapitał Ludzki, temat konkursu Modernizacja oferty kształcenia zawodowego w powiązaniu z potrzebami lokalnego/regionalnego rynku pracy.

43 Więcej o projekcie [w:] M. Rouba (red.), Kształcenie zawodowe. Wszyscy tworzymy jakość. Publikacja główna, Starostwo Powiatowe w Toruniu, Toruń 2013. 
Rys. 2. Powiat toruński - lider i partner w unijnych projektach.

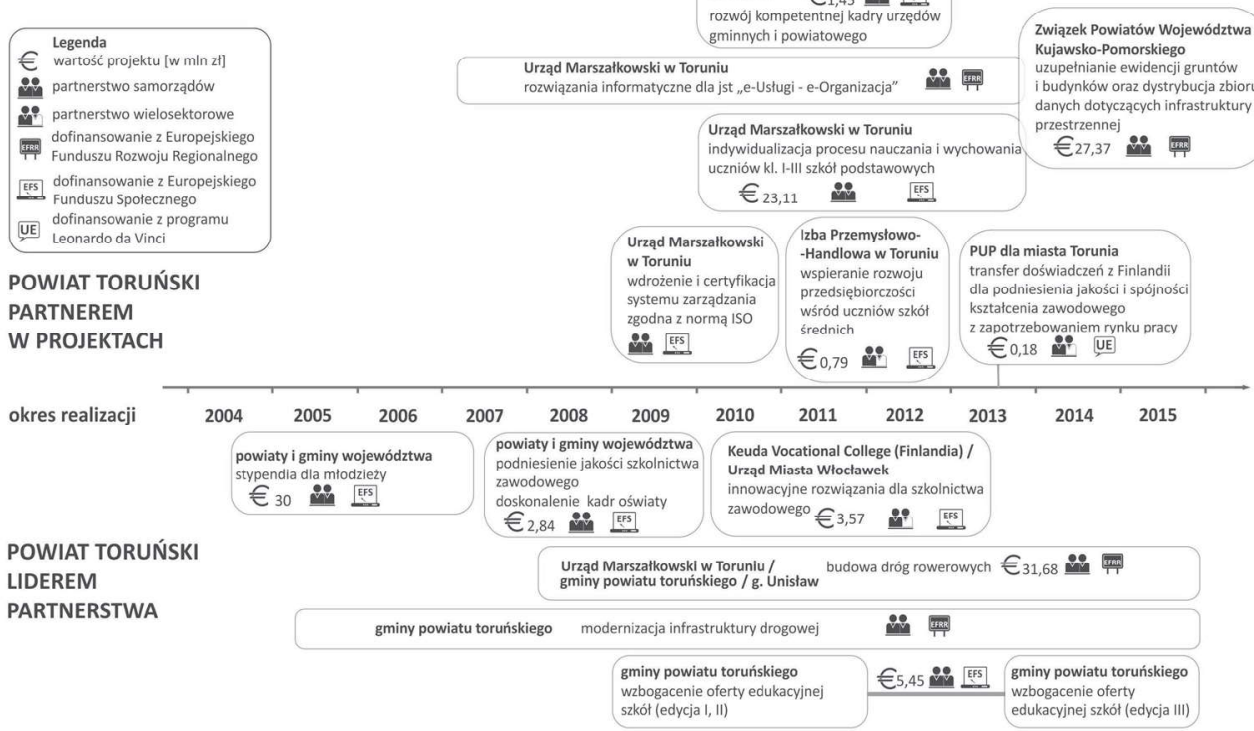

Źródło: M. Rouba (opr.), 15 lat powiatu toruńskiego...

Liczbę i tematykę projektów dofinansowanych z funduszy unijnych prowadzonych przez powiat toruński i jego jednostki organizacyjne w latach 20042014 obrazuje zestawienie: ${ }^{44}$

Projekty powiatu toruńskiego:

- „Pomoc stypendialna dla uczniów szkół ponadgimnazjalnych województwa kujawsko-pomorskiego - edycja 2004/2005", realizowany w latach 2004-2005, o wartości 8756 897,91 zł;

- „Pomoc stypendialna dla uczniów szkół ponadgimnazjalnych województwa kujawsko-pomorskiego - edycja 2005/2006", realizowany w latach 2005-2006, o wartości 12498 604,00 zł;

- „Pomoc stypendialna dla uczniów szkół ponadgimnazjalnych województwa kujawsko-pomorskiego - edycja 2006/2007', realizowany w latach 2006-2007, o wartości 9608 431,68 zł;

- „Podniesienie atrakcyjności i jakości szkolnictwa zawodowego na terenie województwa kujawsko-pomorskiego w roku szkolnym 2008/2009", realizowany w latach 2008-2009, o wartości 2000 000,00 zł;

44 W zestawieniu nie uwzględniono projektów, w których powiat toruński lub jego jednostki organizacyjne uczestniczyli jako partnerzy. 
- „Nauczyciel uczący się - podniesienie kwalifikacji kadr systemu oświaty z terenu byłego województwa toruńskiego w latach 2008 i 2009", realizowany w latach 2008-2009, o wartości 839 300,00 zł;

- „Lepsza szkoła, lepszy zawód - wzmocnienie oferty edukacyjnej szkolnictwa zawodowego w powiecie toruńskim w roku szkolnym 2009/2010", realizowany w latach 2009-2010, o wartości 385 655,00 zł;

- „Czego Jaś się nie nauczy... - wzbogacenie oferty edukacyjnej szkół realizujących kształcenie ogólne z terenu powiatu toruńskiego w roku szkolnym 2009/2010", realizowany w latach 2009-2010, o wartości 1514 459,00 zł;

- „Wszechstronny absolwent na rynku pracy - wzmocnienie oferty edukacyjnej szkolnictwa zawodowego w powiecie toruńskim w roku szkolnym 2010/2011", realizowany w latach 2010-2011, o wartości 334 164,00 zł;

- „Z Małgosią po naukę”, realizowany w latach 2010-2011, o wartości $1594764,00 \mathrm{zl}$

- „Szkoła innowacyjna i konkurencyjna - dostosowanie oferty szkolnictwa zawodowego do wymagań lokalnego rynku pracy", realizowany w latach 2010-2013, o wartości 3571 073,60 zł;

- „Dobry zawód, dobry start”, realizowany w latach 2011-2012, o wartości $370346,00 \mathrm{zt}$;

- „SZkOlna kuźnia Profesjonalistów”, realizowany w latach 2012-2014, o wartości 749 100,00 zł;

- „Zawodowy paszport do kariery”, realizowany w latach 2014-2015, o wartości $1622753,00 \mathrm{zk}$;

- „EU-geniusz i szkoła tajemnic”, realizowany w latach 2014-2015, o wartości 3038 456,00 zt;

- „Modernizacja drogi powiatowej nr 2016 Łubianka-Kończewice od km 5+050 do $\mathrm{km} \mathrm{6+000} \mathrm{na} \mathrm{długości} \mathrm{0,950} \mathrm{km} \mathrm{w} \mathrm{m.} \mathrm{Warszewice",} \mathrm{realizowany}$ w latach 2005-2006, o wartości 946245,15 zł;

- „Przebudowa drogi powiatowej nr 2010 Turzno-Rogówko-Lubicz dolny w km 3+247 do km 4+582 na długości 1,335 km", realizowany w roku 2006, o wartości 831 295,01 zł;

- „Przebudowa drogi powiatowej nr 2021 Świerczynki-Ostaszewo od km 4+281 do km 5+321 na dł. 1,040 km", realizowany w latach 2005-2007, o wartości 953443,71 zł; 
- „Poprawa bezpieczeństwa na drogach publicznych poprzez wybudowanie dróg rowerowych - droga rowerowa: Toruń-Łubianka-Wybcz-Unisław", realizowany w latach 2008-2013, o wartości 6627 287,50 zt;

- „Poprawa bezpieczeństwa na drogach publicznych poprzez wybudowanie dróg rowerowych - droga rowerowa: Toruń-Złotoria-Osiek", realizowany w latach 2008-2014, o wartości 4410 641,00 zł;

- „Poprawa bezpieczeństwa na drogach publicznych poprzez wybudowanie dróg rowerowych - droga rowerowa: Toruń-Chełmża z odgałęzieniem do m. Kamionki Małe", realizowany w latach 2008-2015, o wartości $16800602,75 \mathrm{zl}$;

- „Przebudowa drogi powiatowej nr 2019C Chełmża-Brąchnowo-Pigża

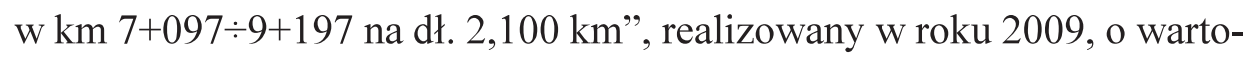
ści 1127 641,23 zł;

- „Przebudowa drogi powiatowej nr 2021 Świerczynki-Kowróz-Ostaszewo w km 5+321 $\div 6+822$ na dł. 1,501 km", realizowany w roku 2009, o wartości $982882,28 \mathrm{zt}$;

- „Przebudowa drogi powiatowej nr 2023C Chełmża-Świętosław-Węgorzyn w km 1+236 $\div 3+036$ na dł. 1,800 km (roboty podstawowe i uzupełniające)", realizowany w roku 2009, o wartości 1362 298,04 zł;

- „Przebudowa systemu ogrzewania budynku i przygotowania ciepłej wody użytkowej poprzez zastosowanie zespołu pomp ciepła wykorzystujących energię geotermiczną ziemi dla DPS w Pigży", realizowany w latach 20092010, o wartości 582856,47 z;;

- „Przebudowa i dostosowanie do obowiązujących standardów dla Domów Pomocy Społecznej Budynku Zespołu nr 2 DPS w Browinie", realizowany w roku 2010, o wartości 2536 451,83 zł;

- „Adaptacja pomieszczeń budynku warsztatowego na pracownie spawalnictwa z zapleczem szkoleniowym i socjalnym", realizowany w latach 2011-2012, o wartości 730 799,97 zł;

- „Przebudowa drogi powiatowej nr 2011C Turzno-Papowo Toruńskie w km

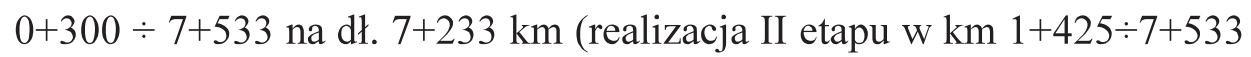
na dł. 6,108 km)", realizowany w roku 2012, o wartości 3690 109,61 zł;

- „Termomodernizacja budynku warsztatów Zespołu Szkół, Centrum Kształcenia Ustawicznego w Gronowie", realizowany w latach 2012-2014, o wartości 1159 916,23 zł; 
- „Zmiana systemu ogrzewania i przygotowania ciepłej wody użytkowej budowa pomp ciepła - przygotowanie inwestycji w DPS w Dobrzejewicach", realizowany w roku 2014, o wartości 1595 942,00 zł;

- „Przygotowanie infrastruktury pod szkolnictwo zawodowe - rolnicze. Adaptacja i dostosowanie oraz wyposażenie istniejących pomieszczeń na pracownię eksploatacji pojazdów rolniczych, pracownię diagnostyki obsługi i kontroli maszyn rolniczych oraz salę wykładową w budynku warsztatów szkolnych Zespołu Szkół Centrum Kształcenia Ustawicznego w Gronowie", realizowany w roku 2014, o wartości 823 528,02 zł;

Projekty Domu Pomocy Społecznej w Browinie:

- „Aktywizacja społeczna mieszkańców DPS w Browinie”, realizowany w roku 2010, o wartości 49 994,00 zł;

- „Integrujmy się poprzez teatr”, realizowany w latach 2010-2011 (dla Środowiskowego Domu Samopomocy), o wartości 46 303,00 zł;

- „Przyroda wokół nas integruje najpiękniej”, realizowany w roku 2011, o wartości 49565,00 zł;

- „Ukryte talenty w ŚDS”, realizowany w roku 2011 (dla Środowiskowego Domu Samopomocy), o wartości 49 242,00 zł;

- „Jutro My”, realizowany w roku 2011, o wartości 407 128,00 zł;

- „Aktywizacja muzyczno-plastyczna mieszkańców DPS”, realizowany w roku 2011, o wartości 46 957,00 zł;

Projekt Domu Pomocy Społecznej w Pigży:

- „Inni w postrzeganiu świata, równi w potrzebach - integracja poprzez sztukę", realizowany w roku 2012, o wartości 49 645,00 zł;

Projekt Powiatowego Centrum Pomocy Rodzinie w Toruniu:

- „Uwierzyć w siebie - aktywna integracja osób przebywających w rodzinach zastępczych i je opuszczających", realizowany w latach 2010-2014, o wartości 1231 553,48 zł;

Projekty Powiatowego Urzędu Pracy dla Powiatu Toruńskiego:

- „Szansa dla młodych”, realizowany w latach 2004-2005, o wartości $1072200,00 \mathrm{zł}$;

- „Powrót na rynek pracy”, realizowany w latach 2004-2005, o wartości 246 600,00 zł;

- „Powrót na rynek pracy”, realizowany w latach 2005-2006, o wartości $1099000,00 \mathrm{zk}$; 
- „Młodzież na rynku pracy”, realizowany w latach 2005-2006, o wartości 1791 300,00 zł;

- „Kobiety na rynku pracy”, realizowany w latach 2005-2006, o wartości $1495923,30 \mathrm{zk}$;

- „Szansa dla kobiet”, realizowany w latach 2006-2007, o wartości 1306834,20 zł;

- „Startuj od nowa”, realizowany w latach 2006-2007, o wartości 2451600,00 zł;

- „Moja kariera”, realizowany w latach 2006-2008, o wartości 2920 343,00 zł;

- „Profesjonalny Urząd”, realizowany w latach 2008-2009, o wartości $200240,00 \mathrm{zt}$;

- „Moja praca - moja przyszłość”, realizowany w latach 2008-2014, o wartości $30589811,64 \mathrm{zt}$;

- „Przyjazny Urząd”, realizowany w latach 2009-2010, o wartości 158 400,00 zt;

- „Skuteczny Urząd”, realizowany w latach 2010-2011, o wartości $186322,00 \mathrm{zt}$;

- „Kompetentny Urząd”, realizowany w latach 2011-2012, o wartości $186321,65 \mathrm{zk}$;

- „Efektywny Urząd”, realizowany w latach 2012-2014, o wartości 372 631,16 zł;

- „Wsparcie na dobry początek”, realizowany w latach 2012-2013, o wartości 865 087,10 zł;

- „Skuteczny Urząd 2014”, realizowany w latach 2014-2015, o wartości $173100,00 \mathrm{zk}$;

Projekty Zespołu Szkół Centrum Kształcenia Ustawicznego w Gronowie:

- „Równe szanse w drodze do poszerzania kompetencji kluczowych”, realizowany w latach 2008-2009, o wartości 229 602,97 zł;

- „Dobre doradztwo $=$ dobre kształcenie $=$ sukces zawodowy”, realizowany w latach 2008-2010, o wartości 307 444,70 zł;

- „Dobre szkolenie w drodze do poszerzenia kompetencji”, realizowany w roku 2009, o wartości 125 129,54 zł;

- „Atrakcyjna szkoła w trosce o pokolenia”, realizowany w latach 20092010, o wartości 524 385,00 zł;

- „Nigdy nie jest za późno na naukę”, realizowany w latach 2009-2010, o wartości 524 548,00 zł; 
- „Szkoła przyszła do ciebie”, realizowany w latach 2010-2014, o wartości $7559650,00 \mathrm{zk}$;

- „Szkoła przyszła do ciebie - wykorzystaj tę szansę”, realizowany w latach 2014-2015, o wartości 1865 075,00 zł.

Przez 15 lat funkcjonowania powiat toruński zrealizował inwestycje za ponad 131,41 mln złotych. 40\% wykorzystanych środków stanowiły środki własne powiatu, $43 \%$ pochodziło $\mathrm{z}$ innych źródeł, natomiast $17 \%$ wyniosły pieniądze $\mathrm{z}$ UE, pozyskane $\mathrm{w}$ ramach środków przedakcesyjnych (PHARE, SAPARD) oraz funduszy strukturalnych. Gdyby nie skuteczne starania o europejskie wsparcie, jednej piątej wszystkich działań i inwestycji bez wątpienia nie udałoby się władzom powiatu przeprowadzić. Ilościowy i jakościowy awans, jaki nastąpił wraz z rokiem 2004 w pozyskiwaniu przez powiat dodatkowych środków, ilustruje poniższy wykres:

Rys. 3. Aktywność samorządu powiatowego w pozyskiwaniu dodatkowych środków na realizację zadań statutowych.

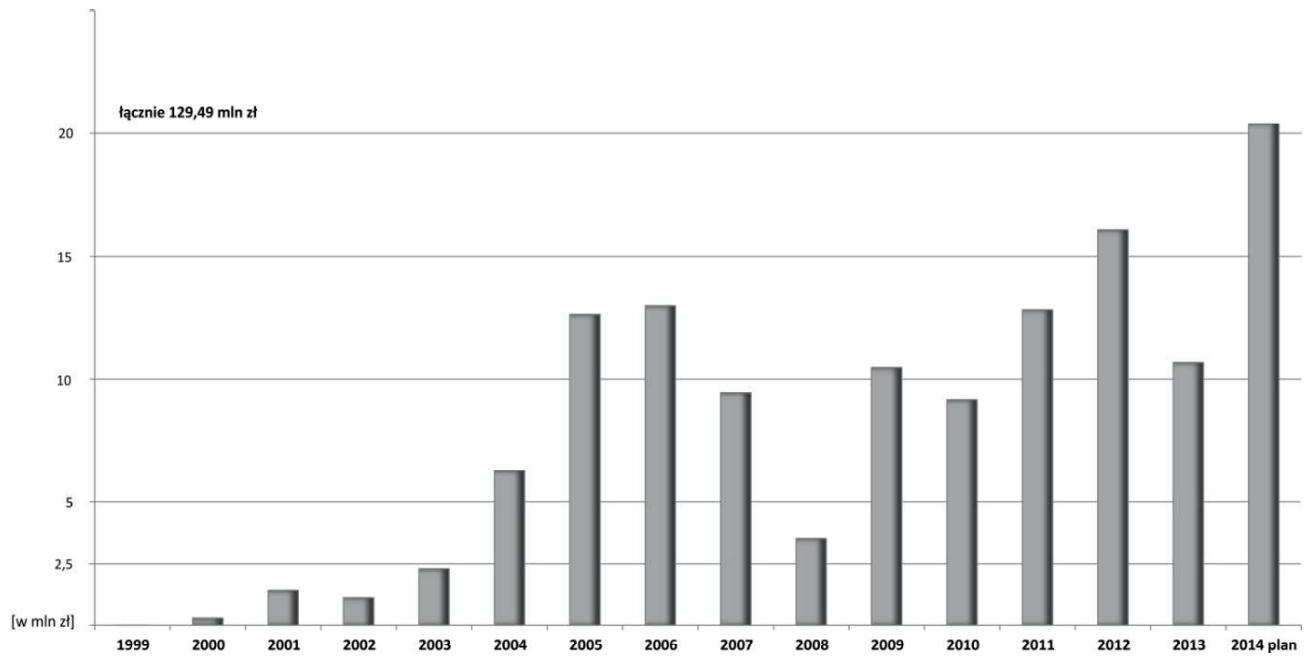

Źródło: M. Rouba (opr.), 15 lat powiatu toruńskiego...

Działalność i aktywność powiatu toruńskiego poddawana jest systematycznej ocenie. Tę najistotniejszą z punktu widzenia władz i pracowników instytucji samorządowych wystawiają co cztery lata wyborcy. Nie jest to jednak jedyna forma weryfikacji osiągnięć samorządu. Od 11 lat pozycję powiatu toruńskiego na tle kraju odzwierciedla największy branżowy Ogólnopolski Ranking Powiatów, prowadzony przez Związek Powiatów Polskich. Jego osiągnięcia 
porównywane są tam ze 152 powiatami z całego kraju w kategorii ,,powiaty od 60 do 120 tys. mieszkańców". Ocena następuje wg kilkudziesięciu kryteriów zgrupowanych w kilku lub kilkunastu kategoriach, dostosowywanych corocznie do zmieniających się realiów działalności samorządu terytorialnego. W roku 2015 obowiązywały następujące kategorie, obejmujące praktycznie wszystkie obszary powiatowej aktywności: ${ }^{45}$

- działania proinwestycyjne i prorozwojowe,

- rozwiązania poprawiające jakość obsługi mieszkańca oraz funkcjonowania jednostki samorządu terytorialnego,

- rozwój społeczeństwa informacyjnego,

- rozwój społeczeństwa obywatelskiego,

- umacnianie systemów zarządzania bezpieczeństwem urzędu,

- promocja rozwiązań z zakresu ochrony zdrowia i pomocy społecznej,

- promocja rozwiązań z zakresu edukacji, kultury i sportu,

- wspieranie działań na rzecz społecznej gospodarki rynkowej,

- promocja rozwiązań ekoenergetycznych i proekologicznych,

- współpraca krajowa i międzynarodowa,

- działania promocyjne.

Na przestrzeni minionych lat pozycja powiatu toruńskiego w rankingu była zmienna, jednak usystematyzowanie podejmowanych działań i konsekwencja w dążeniu do wyznaczonych celów wpłynęły na stanowczą poprawę lokaty i zaistnienie w krajowej czołówce. Przełom stanowił rok 2009, kiedy powiat toruński uplasował się na miejscu 37. w kraju i 2. w województwie. Kolejne lata to odpowiednio miejsca: 2010 (kraj - 40., województwo - 2.), 2011 (29./2.), 2012 (11./2.). W 2013, zachowując 11. pozycję w skali kraju, powiat toruński wysunął się na 1. lokatę w województwie. W 2014 poprawił pozycję krajową (7) lecz utracił prymat wojewódzki (2), by w 2015 dalej unieść się w ogólnopolskim rankingu (6), odzyskując miejsce kujawsko-pomorskiego lidera (1).

45 Załącznik nr 3 do uchwały nr 20/15 Zarządu V kadencji z dnia 4 maja 2015 r. Regulamin Rankingu Powiatów o wielkości od 60 tys. do 120 tys. mieszkańców na rok 2015. 
Rys. 4. Pozycja powiatu toruńskiego w Rankingu Powiatów Związku Powiatów Polskich na przestrzeni lat.

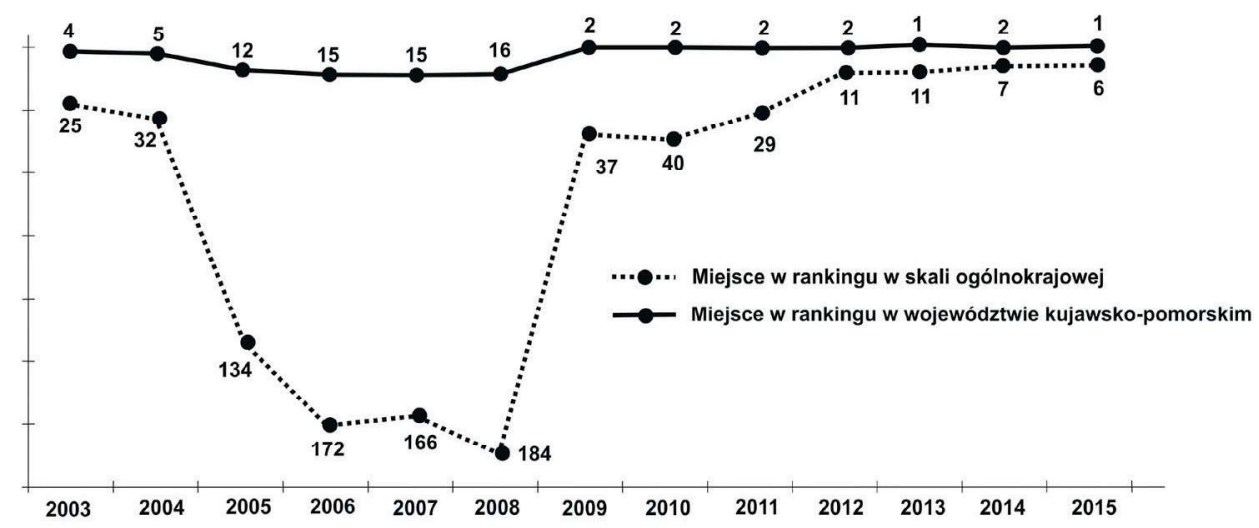

Źródło: opracowanie własne Wydziału Promocji i Rozwoju Starostwa Powiatowego w Toruniu.

Powiat toruński jest również wielokrotnym laureatem konkursu „Gospodarczo-Samorządowy HIT Kujaw i Pomorza”, przeznaczonego dla samorządów i przedsiębiorców, którzy rywalizują w kategoriach najlepszych usług, produktów, przedsięwzięć ekologicznych, organizacyjnych i zarządczych. Pierwszy tytuł, HIT 2002, Starostwo Powiatowe w Toruniu otrzymało za restrukturyzację i prywatyzację SPZOZ w Chełmży w spółkę prawa handlowego pod nazwą Szpital Powiatowy w Chełmży, natomiast pozostałe trzy tytuły - przyznane już po wejściu Polski do UE - były dowodem uznania dla jakości realizowanych przez powiat unijnych projektów (własnych bądź w partnerstwie): w 2006 roku HIT za efektywną koordynację projektu „Pomoc stypendialna dla uczniów szkół ponadgimnazjalnych województwa kujawsko-pomorskiego", w 2011 r. Kryształowy HIT za systemowe doskonalenie modelu organizacji pracy i obsługi klienta, a w 2014 roku Rubinowy HIT za promowanie atrakcji turystycznych regionu i poprawę bezpieczeństwa na drogach poprzez budowę sieci dróg rowerowych.

Rok 2006 przyniósł powiatowi toruńskiemu tytuł „Powiat otwarty na fundusze strukturalne", przyznany przez Związek Powiatów Polskich w ramach projektu „Powiaty i Gminy otwarte na fundusze strukturalne”, natomiast w roku 2009 ZPP uhonorował Starostę Toruńskiego tytułem Samorządowca Dziesięciolecia. W 2010 Starosta otrzymał Medal Marszałka Województwa Kujawsko-Pomorskiego za wkład w rozwój samorządności na Kujawach i Pomorzu oraz pracę na rzecz mieszkańców regionu, kształtowanie jego 
tożsamości i wzmacnianie integralności. Skuteczna promocja i sukcesywne budowanie przez lata marki powiatu toruńskiego zaowocowały zajęciem w 2013 roku przez powiat toruński drugiego miejsca w konkursie „Markowy Samorząd", organizowanym przez Wolters Kluwer Polska, gdzie do zmagań stanęło ponad 900 jednostek samorządowych różnego szczebla z całego kraju.

\section{Podsumowanie}

Po 25 latach od decentralizacji systemu władzy publicznej, samorząd terytorialny stał się integralną składową systemu władzy publicznej, a idea samorządności wydaje się mocno ugruntowana w polskim społeczeństwie. Podobnie rzecz się ma ze świadomością przynależności Polski do struktur europejskich. Pomimo początkowych obaw, obecnie zdecydowana większość Polaków (81\%) popiera członkostwo naszego kraju w Unii Europejskiej. Sprzeciw wyraża już tylko co dziesiąty rodak $(10 \%)^{46}$.

Niewątpliwie jedną z najsilniejszych determinant takiego podejścia stanowi strumień funduszy europejskich, którymi nasz kraj został zasilony w ubiegłych dwunastu latach. Prorozwojowy wpływ funduszy widoczny jest w polskich miejscowościach na każdym kroku w postaci m.in. dróg, mostów, środków komunikacji, budynków użyteczności publicznej, zrewitalizowanych obszarów miejskich, placów zabaw i obiektów sportowych czy dokapitalizowanej polskiej wsi. Dzięki temu 41\% Polaków uważa, że Unia Europejska wywarła duży wpływ na rozwój polskich miejscowości. ${ }^{47}$ Nie powinien zatem budzić zdziwienia fakt, że poparcie dla naszej obecności w zjednoczonej Europie jest szczególnie wysokie wśród samorządowców - 85\% przedstawicieli samorządu terytorialnego uważa, że członkostwo w UE jest korzystne dla mieszkańców i władz samorządu, a przeciwnego zdania jest zaledwie 2 do $6 \%{ }^{48}$. Samorządowcy zawdzięczają bowiem europejskiej integracji: napływ inwestycji do samorządu (77\%), polepszenie infrastruktury transportowej (76\%), polepszenie infrastruktury sportowej (75\%), polepszenie infrastruktury społecznej [budynki użyteczności publicznej] (73\%), nowe możliwości edukacyjne (70\%), rozwój rolnictwa i modernizację gospodarstw rolnych (65\%), rozwój turystyki (65\%),

\footnotetext{
46 Komunikat z badań CBOS nr 31/2016 - Polska w Unii Europejskiej, Fundacja Centrum Badania Opinii Społecznej, Warszawa, luty 2016.

47 Komunikat $\mathrm{z}$ badań CBOS nr 69/2015 - 25 lat państwa obywatelskiego...

$48 \quad$ Ł. Wenerski, Unia daje czy zabiera?..., s. 21.
}

\section{4}


rozwój współpracy międzynarodowej samorządu (54\%), pozycję samorządu na arenie międzynarodowej (50\%) czy powstanie nowych miejsc pracy $(44 \%)^{49}$.

Powiat toruński, wraz ze swoimi mieszkańcami, z pewnością jest dużym wygranym procesu integracji. Podczas lat intensywnej pracy udało się pozyskać wielomilionowe kwoty wsparcia z unijnych funduszy, zbudować liczne partnerstwa, wyznaczyć nowe kierunki myślenia i działania. Dzięki temu zrealizowane zostało kilkadziesiąt projektów zarówno z grupy „twardych”inwestycyjnych, jak i „miękkich” - wspierających kapitał ludzki. Udało się spowodować znaczący skok jakościowy w zakresie wzrostu poziomu wiedzy i kompetencji dzieci, młodzieży i dorosłych, komfortu i bezpieczeństwa mieszkańców, poprawy dostępu do usług medycznych, jakości dróg, szkolnictwa, dostępu do infrastruktury sportowej, obsługi interesantów czy opieki w domach pomocy społecznej. Również wszystkie gminy wchodzące w skład powiatu oraz liczne firmy i organizacje działające na tym terenie odnotowały znaczne sukcesy w realizacji działań sfinansowanych z unijnych środków. Według danych z prowadzonego przez Ministerstwo Rozwoju systemu KS SIMIK wykorzystanie środków z budżetu UE w formie dofinansowania realizowanych projektów dało powiatowi toruńskiemu trzecie, po powiatach inowrocławskim i bydgoskim, miejsce w województwie kujawsko-pomorskim wśród powiatów tzw. ziemskich. Na dzień 31.12.2015 r. suma unijnych środków zainwestowanych na terenie powiatu toruńskiego wyniosła łącznie 468617 259,43 złotych. W rozbiciu na poszczególne programy były to odpowiednio: Program Operacyjny Infrastruktura i Środowisko - 173878 985,34; Program Operacyjny Innowacyjna Gospodarka - 18745 349,65; Program Operacyjny Kapitał Ludzki (krajowy i regionalny) - 82976 766,80; Regionalny Program Operacyjny Województwa Kujawsko-Pomorskiego - 193016 157,64.

Perspektywa 2014-2020, choć konkursy realizowane w jej ramach ogłaszane są ze znacznym opóźnieniem, powinna zostać przez polskie samorządy wykorzystana w jak najwyższym stopniu. Jest już bowiem ostatnią, podczas której unijne pieniądze tak szerokim strumieniem zasilają nasz kraj. Dlatego powiat toruński z pewnością dołoży wszelkich starań, by jak najskuteczniej i jak najpełniej zaabsorbować dostępne środki, tak by tę jedyną w swoim rodzaju szansę możliwie najlepiej wykorzystać. Głównymi problemami z jakimi z pewnością przyjdzie mu się zmierzyć będą niedobór zaufania okazywanego samorządom przez władzę centralną i nadmierna w ich odczuciu ingerencja

49 Tamże, s. 23. 
w sprawy leżące w zakresie kompetencji jednostek samorządu terytorialnego, przerośnięta i ciągle zwiększająca się formalizacja postępowań konkursowych o dofinansowanie unijnych projektów, niski i wciąż zmniejszający się poziom wsparcia ze strony instytucji wdrażających, zarządzających i pośredniczących, brak lub niedostateczna współpraca pomiędzy samorządami poszczególnych szczebli. Tym niemniej powiat - jego władze i pracownicy - z pewnością nie ustaną w wysiłkach, by dalej odnosić jak największe korzyści z naszego członkostwa w Unii Europejskiej i by dzięki realizowanym projektom wspierającym rozwój i poprawę infrastruktury, bezpieczeństwa i komfortu życia mieszkańców oraz ciągłemu inwestowaniu w kapitał ludzki, poziom życia lokalnej społeczności mógł systematycznie wzrastać.

\section{Literatura}

1. 10 PL-UE. Polskie 10 lat w Unii. Raport, praca zbiorowa, Ministerstwo Spraw Zagranicznych, Warszawa 2014.

2. Dąmbska A., Trzyna S. (red.), Samorzad 3.0 Raport Forum Od-nowa, Forum Od-nowa, Warszawa, listopad 2013.

3. Lutrzykowski A. (red.), Polski samorzad terytorialny. Europejskie standardy i krajowa specyfika, Wydawnictwo Adam Marszałek, Torun 2014.

4. Małecki J., Bystrzycki A., Środowisko przyrodnicze powiatu toruńskiego, Starostwo Powiatowe w Toruniu, Toruń 2000.

5. Miłoszewski H., Powiat toruński-przewodnik, Lokalna Organizacja Turystyczna Toruń, Toruń 2007.

6. Narastajace dysfunkcje, zasadnicze dylematy, konieczne dziatania. Raport o stanie samorzadności terytorialnej w Polsce, praca zbiorowa, Małopolska Szkoła Administracji Publicznej, Kraków 2013.

7. Osiecka J., Opinia publiczna o integracji europejskiej - wyzwania dla polityki informacyjnej państwa, Raport nr 156, Biuro Studiów i Ekspertyz Sejmu RP, Warszawa 1999.

8. Rouba M. (opr.), 15 lat powiatu toruńskiego, Starostwo Powiatowe w Toruniu, Toruń 2014.

9. Rouba M. (red.), Ksztatcenie zawodowe. Wszyscy tworzymy jakość. Publikacja główna, Starostwo Powiatowe w Toruniu, Torun 2013.

10. Statystyczne Vademecum Samorzadowca. Powiat toruński, GUS, Bydgoszcz 2015.

11. Statystyczne Vademecum Samorządowca. Województwo kujawsko-pomorskie, GUS, Bydgoszcz 2015.

12. Szymańczak J., Konferencja Od przeszłości do przyszłości samorządu powiatowego, Warszawa, 18 lutego 2013 r., Kancelaria Sejmu, Warszawa 2013.

13. Wenerski Ł., Unia daje czy zabiera? Dekada członkostwa polski w UE w oczach przedstawicieli polskich samorządów, Instytut Spraw Publicznych, Warszawa 2013. 
14. Województwo kujawsko-pomorskie w 1998 r., Ważniejsze dane o województwie, powiatach, gminach, WUS, Bydgoszcz 1999.

15. Zając J., Wojewódzka A., Stawicki M., Uwarunkowania absorpcji funduszy strukturalnych UE na poziomie powiatów. Analiza i rekomendacje, SGGW, Warszawa 2009.

Malwina Rouba

Starostwo Powiatowe w Toruniu 